\title{
Controlling Plug Height of Verbena, Celosia, and Pansy by Treating Seeds with Paclobutrazol
}

\author{
Stanislav V. Magnitskiy, ${ }^{1}$ Claudio C. Pasian, ${ }^{2}$ Mark A. Bennett, and \\ James D. Metzger \\ Department of Horticulture and Crop Science, The Ohio State University, \\ 2001 Fyffe Court, Columbus, OH 43210
}

Additional index words. Verbena $\times$ hybrida, Viola wittrockiana, Celosia cristata, seeds, plant growth regulator, bedding plant, seedling height, seedling emergence, seed soaking, seed priming, seed coating

\begin{abstract}
Shoot stretching in plug production reduces quality and makes mechanized transplanting difficult. The objectives of this study were to measure seedling emergence and shoot height of plugs as affected by paclobutrazol application during seed soaking, priming, or coating on seedling emergence and height. Verbena (Verbena $\times$ hybrida Voss. 'Quartz White'), pansy (Viola wittrockiana L. 'Bingo Yellow Blotch'), and celosia (Celosia cristata L. 'New Look') seeds were soaked in water solutions of paclobutrazol and subsequently dried on filter paper at $20{ }^{\circ} \mathrm{C}$ for $24 \mathrm{~h}$. Soaking seeds in paclobutrazol solutions before sowing reduced growth and percentage seedling emergence of verbena and pansy but had little effect on those of celosia. Verbena seeds soaked in 50, 200, or $500 \mathrm{mg}$ paclobutrazol/L for 5,45 , or $180 \mathrm{~min}$ produced fewer and shorter seedlings than controls. Osmopriming verbena seeds with 10 to $500 \mathrm{mg}$ paclobutrazol/Lreduced seedling emergence. Seedling height and emergence percentage of pansy decreased with increasing paclobutrazol concentrations from 2 to $30 \mathrm{mg} \cdot \mathrm{L}^{-1}$ and with soaking time from 1 to 5 min. The elongation of celosia seedlings was reduced by soaking seeds in 10, 50, 200, or $500 \mathrm{mg}$ paclobutrazol/L solutions for 5,180 , or $360 \mathrm{~min}$. However, these reductions were negligible and without any practical application.
\end{abstract}

Controlling excessive plant growth without changing developmental patterns or causing phytotoxicity is one of several challenges in greenhouse production of bedding plants. Plant growth regulators, when used properly, can restrict plant growth without side effects (Rademacher, 2000). An important group of commercial plant growth regulators are the triazole compounds such as paclobutrazol. Paclobutrazol inhibits the oxidation of entkaurene to ent-kaurenoic acid, an early reaction in gibberellin (GA) biosynthesis (Fletcher et al., 2000; Rademacher, 2000). Inhibition of GA biosynthesis leads to reduction of growth, internode length and leaf area (Gent, 1997; Klock, 1998; Million et al., 1999). Secondary activities of paclobutrazol are associated with changes in the endogenous levels of abscisic acid, cytokinin, and antioxidants (Fletcher et al., 2000; Rademacher, 2000.

Received for publication 30 June 2005. Accepted for publication 6 Oct. 2005. We thank Monica Kmetz-Gonzalez for assistance with growing plants, David Tay for help with seed coating equipment and technique, and Bert Bishop for assistance in data analysis. Salaries and research support were provided in part by State and Federal funds appropriated to the Ohio Agricultural Research and Development Center, The Ohio State University. Journal article HCS 05-XXX. No endorsement is intended for products mentioned in this article, nor is criticism meant for products not mentioned.

${ }^{1}$ Current address: Department of Agronomy, National University of Colombia, Building 500, Bogotá, Colombia.

${ }^{2}$ To whom reprints requests should be addressed; e-mail pasian.1@osu.edu.
Growth regulators are mainly applied to plants as root or foliar treatments. Both methods can result in losses of growth regulators by adsorption to the substrate or drift away from the target (Klock, 1998; Million et al., 1999; Fletcher et al., 2000). These losses reduce effectiveness and increase the cost of application. Low phloem mobility of paclobutrazol further reduces the effectiveness of the foliar applications of this chemical (Hamid and Williams, 1997). Presowing seed treatment is a novel approach in the delivery of growth regulators to plants. It may be of high practical value in the regulation of plant growth and resistance to stress (Fletcher et al., 2000). However, several studies indicated that seed treatments with growth regulators exhibited a number of practical disadvantages, such as delay and reduction in seedling emergence (Pill and Gunter, 2001). Soaking seeds in 50 to $100 \mathrm{mg} \cdot \mathrm{L}^{-1}$ paclobutrazol solutions controlled the overgrowth of rice seedlings (Choi et al., 1988). Soaking maize kernels in 80 or $160 \mathrm{mg} \cdot \mathrm{L}^{-1}$ paclobutrazol for $16 \mathrm{~h}$ resulted in a temporary growth reduction of seedlings without decreasing seedling emergence (Dale and Drennan, 1997). Pombo et al. (1985) found a reduction in seedling growth when tomato seeds were germinated on a silicate gel containing $5 \mathrm{mg} \cdot \mathrm{L}^{-1}$ paclobutrazol. Soaking seeds in $1000 \mathrm{mg} \cdot \mathrm{L}^{-1}$ paclobutrazol solutions for 6,16 , or $24 \mathrm{~h}$ resulted in respective growth reductions of $31 \%, 31 \%$, or $40 \%$ in tomato, $61 \%, 37 \%$, or $76 \%$, in geranium, and $30 \%, 38 \%$, or $41 \%$, in marigold (Pasian and Bennett, 2001). Soaking seeds in $500 \mathrm{mg} \cdot \mathrm{L}^{-1}$ paclobutrazol solutions for $12 \mathrm{~h}$ was the most effective treatment in growth retardation of cucumber (Cho et al., 2002).

Coating seeds as a means of delivering growth regulators would require less application time and avoid excessive seed imbibition compared to soaking. In addition, coating formulations easily adhere to the seed surface and may reduce penetration of growth regulators into seeds and the potential to embryo injury. Although Pill and Gunter (2001) suggested priming seeds with growth regulators as a potential method for seedling growth control, no published data is available comparing effects on seedling growth when using different methods of treating seeds with growth regulators.

The objectives of the present study were to a) measure the effects of paclobutrazol dose and seed soaking times on height and emergence of verbena, pansy, and celosia seedlings and b) compare paclobutrazol soaking, priming, and coating seed treatments on verbena seedling emergence and plug height.

\section{Materials and Methods}

Plant materials and chemicals. The species under study included verbena, pansy, and celosia. The growth regulator used was paclobutrazol ( $\beta$-[(4-chlorphenyl)methyl]$\alpha$-(1,1-dimethylethyl)-1H-1,2,4-triazole-1ethanol) in the Bonzi formulation (Uniroyal Chemical Company, Middlebury, Conn.) containing $0.4 \%$ active ingredient.

Seed soaking. Seeds were soaked in water or water solutions of paclobutrazol, while nontreated seeds represented the controls. In each treatment, 100 seeds were placed in a glass beaker with $50 \mathrm{~mL}$ paclobutrazol solution or water. During seed soaking, the solutions were constantly agitated on a slow variable rotating shaker (Koala-Ty; Accurate Chemical and Scientific Corp., Westbury, N.Y.). Verbena seeds were soaked in $0,50,200$, or $500 \mathrm{mg}$ paclobutrazol/L solutions for 5,45 , or 180 min. Pansy seeds were soaked in $0,2,10$, or $30 \mathrm{mg}$ paclobutrazol/L solutions for 1 or 5 min. Celosia seeds were soaked in $0,10,50$, 200 , or $500 \mathrm{mg}$ paclobutrazol/L solutions for 5,180 , or $360 \mathrm{~min}$. After soaking, seeds were transferred to a sieve and then dried on filter paper(Whatman International Ltd., Maidstone, U.K.) for $24 \mathrm{~h}$ on an open bench at $20^{\circ} \mathrm{C}$.

Seed priming. Verbena seeds were osmoprimed in water or polyethylene glycol 8000 (PEG) in glass cylinders $(2.0 \mathrm{~cm}$ in diameter $)$ for $26 \mathrm{~h}$ at $20^{\circ} \mathrm{C}$. Nontreated seeds represented the controls. PEG was prepared at $284 \mathrm{~g} \cdot \mathrm{L}^{-1}$ water to provide an osmotic potential of -1.0 MPa (Khan, 1992). Each treatment consisted of 200 seeds placed in a cylinder with 100 $\mathrm{mL}$ priming solution that was aerated with aquarium air pumps. In the during-priming treatment set (DP), seeds were primed in PEG solution prepared with $0,10,50,200$, or $500 \mathrm{mg}$ paclobutrazol/L for $26 \mathrm{~h}$, then rinsed with water $\left(28\right.$ to $30{ }^{\circ} \mathrm{C}$ ) for $1 \mathrm{~min}$. In the after-priming treatment set (AP), seeds were primed for $26 \mathrm{~h}$ in $\mathrm{PEG}$, rinsed with water for $1 \mathrm{~min}$, and then soaked in paclobutrazol solutions for $5 \mathrm{~min}$ as described above. Seed moisture contents at the end of osmopriming 
were $48 \%$ to $52 \%$ (fresh weight basis), which corresponded to the lowest moisture content preceding seed germination in verbena (Carpenter and Maekawa, 1991). In order to achieve this level of seed moisture, $26 \mathrm{~h}$ priming time was found to be optimal. After priming, seeds were dried as described above.

Seed coating. Coating verbena seeds was performed in an open steel pan $(20 \mathrm{~cm}$ diameter and $14 \mathrm{~cm}$ deep). The pan was constantly rotated at 60 to 80 rotations $/ \mathrm{min}$. Seeds were added into the pan and coating formulations were sprayed as a thin mist with the use of an airbrush 6131 (Central Pneumatic, Camarillo, Calif.) over 10 to $15 \mathrm{~min}$. Two commercial film coatings, Celgard 96530 (CelPril, Santa Monica, Calif.) or Disco Shine (Incotec International, Enkuisen, Netherlands) were used. Each was diluted 1:1 with water and applied at $1.5 \mathrm{~mL} / 2.3 \mathrm{~g}$ verbena seeds (1000 seeds) providing even seed coating with no formulation remaining in the pan. In the 'during coating' treatment set (DC), seeds were coated with a coating formulation prepared with 0,10 , or $500 \mathrm{mg}$ paclobutrazol/L. To achieve the necessary paclobutrazol concentration, each coating formulation was initially mixed with the respective amount of undiluted Bonzi formulation. In the after coating treatment set (AC), seeds were coated with the coating formulations only, dried on an open bench for $24 \mathrm{~h}$ and then soaked in 0,10 , or $500 \mathrm{mg} \cdot \mathrm{L}^{-1}$ water solutions of paclobutrazol for $1 \mathrm{~min}$. Seeds were then dried again on filter paper for $24 \mathrm{~h}$ on an open bench at $20^{\circ} \mathrm{C}$.

Plant growth. Within 2 to 4 dafter treatment application, seeds were sown at one seed per cell in plastic 288-cell plug trays (cell depth $3 \mathrm{~cm}$ ) filled with plug growth mix Sunshine
LP5 (Sun Gro Horticulture, Bellevue, Wash.). Each treatment consisted of 100 seeds divided into four replications of 25 seeds each. Each replication was randomly distributed within the plug trays. Seeds were covered with a small portion of the same substrate, and they were placed under intermittent mist at $25^{\circ} \mathrm{C}$ for $1 \mathrm{~d}$. Plug trays were then moved to a $25^{\circ} \mathrm{C}$ greenhouse and randomly arranged on a wet mat-covered bench under natural light conditions. Plugs were watered as needed with tap water and fertilized with Peters Professional water-soluble fertilizer $20 \mathrm{~N}-8.7 \mathrm{P}-16.7 \mathrm{~K}$ (Scotts-Sierra Horticultural Products Co., Marysville, Ohio) at a rate of $2 \mathrm{~g} \cdot \mathrm{L}^{-1}$ every third irrigation. Percentage of seedling emergence was determined 10 and $20 \mathrm{~d}$ after sowing (DAS) (soaking and priming, respectively) for verbena, 8 and 12 DAS for pansy, and 3 and $15 \mathrm{DAS}$ for celosia. Plug height was measured from the substrate surface.

Statistical analysis. Plug height and percentage seedling emergence as a response to growth regulator concentration and soaking time were analyzed to test for significant linear effects using regression analysis in the general linear model procedure in SAS, (SAS Institute, Cary, N.C.). Mean comparisons by LSD were used to evaluate the effect of water treatments (water-treated seeds vs. untreated seeds) on plug height and seedling emergence.

\section{Results}

Seedling emergence and seedling height from water only soaked seeds were not significantly different from the height of seedlings obtained from nonsoaked seeds for all crops tested. All crops, except celosia, appeared to have greener foliage when grown from paclobutrazol-soaked seeds.

\section{Verbena}

Seed soaking. On both 25 and 39 DAS, linear trends of seedling height reductions due to increasing paclobutrazol concentrations were observed for the three soaking times (Table 1). Seedlings obtained from seeds soaked at the lowest concentration of paclobutrazol (50 $\mathrm{mg} \cdot \mathrm{L}^{-1}$ ) were significantly ( $t$ test) shorter than controls (not soaked seeds). Seedling height reductions associated with increasing soaking times at several paclobutrazol concentrations were observed mostly at 39 DAS (Table 1). Soaking seeds in paclobutrazol solutions for 5 min had less effect on reducing seedling height at 39 DAS than soaking seeds for longer times (45 or $180 \mathrm{~min}$ ). Seedlings emerged from seeds soaked in the highest paclobutrazol concentration $\left(500 \mathrm{mg} \cdot \mathrm{L}^{-1}\right)$ for $180 \mathrm{~min}$ were dead by 39 DAS (Table 1).

Seedling emergence was reduced by increasing concentrations of paclobutrazol solution (Table 1). The lowest concentration of paclobutrazol $\left(50 \mathrm{mg} \cdot \mathrm{L}^{-1}\right)$ severely reduced seedling emergence (Table 1). Seedling emergence was also delayed for paclobutrazol-soaked seeds: percentages of seedling emergence at 20 DAS were higher than those at $10 \mathrm{DAS}$. At the highest concentration of paclobutrazol solution $\left(500 \mathrm{mg} \cdot \mathrm{L}^{-1}\right)$ with 45 or 180 min soaking time, no seedling emergence occurred even 20 DAS (Table 1). Increasing soaking time for water only treated seeds had no significant effect on seedling emergence. However, increasing paclobutrazol concentration and soaking times resulted in reduced seedling emergence at 10 and 20 DAS (Table 1).

Table 1. Height (cm) and emergence (\%) of verbena seedlings from seeds soaked in $0,50,200$, or $500 \mathrm{mg} \cdot \mathrm{L}^{-1}$ paclobutrazol solutions during 5, 45, or $180 \mathrm{~min}$. Height measurements and emergence determinations were taken 25 and 39 and 10 and $20 \mathrm{~d}$ after sowing (DAS), respectively.

\begin{tabular}{|c|c|c|c|c|c|c|c|c|c|c|c|c|c|c|c|c|}
\hline \multirow[b]{3}{*}{ Paclobutrazoconcn } & \multicolumn{7}{|c|}{ Shoot ht $(\mathrm{cm})$} & \multicolumn{9}{|c|}{ Emergence (\%) } \\
\hline & \multicolumn{3}{|c|}{$25 \mathrm{DAS}$} & \multicolumn{4}{|c|}{39 DAS } & \multicolumn{4}{|c|}{10 DAS } & \multirow[b]{2}{*}{$\mathrm{L}^{\mathrm{z}}$} & \multicolumn{3}{|c|}{20 DAS } & \multirow[b]{2}{*}{$\mathrm{L}^{\mathrm{z}}$} \\
\hline & $5 \mathrm{~min}$ & $45 \mathrm{~min}$ & $180 \mathrm{~min}$ & $\mathrm{~L}^{\mathrm{z}}$ & $5 \mathrm{~min}$ & $45 \mathrm{~min}$ & $180 \mathrm{~min}$ & $\mathrm{~L}^{\mathrm{z}}$ & $5 \mathrm{~min}$ & $45 \mathrm{~min}$ & $180 \mathrm{~min}$ & & $5 \mathrm{~min}$ & $45 \mathrm{~min}$ & $180 \mathrm{~min}$ & \\
\hline $0 \mathrm{mg} \cdot \mathrm{L}^{-1}$ & 2.7 & 2.8 & 3.0 & NS & 5.0 & 5.0 & 4.4 & $* *$ & 63 & 60 & 67 & NS & 73 & 63 & 70 & NS \\
\hline $200 \mathrm{mg} \cdot \mathrm{L}^{-1}$ & 2.2 & 1.5 & 1.3 & $*$ & 3.9 & 2.8 & 2.7 & $*$ & 7 & 3 & 0 & * & 24 & 7 & 0 & ** \\
\hline $500 \mathrm{mg} \cdot \mathrm{L}^{-1}$ & 1.4 & 0.8 & 0.4 & NS & 3.0 & 1.5 & $--y^{y}$ & NS & 5 & 0 & 0 & NS & 11 & 0 & 0 & $*$ \\
\hline $\mathrm{L}^{\mathrm{x}}$ & $* * *$ & ** & *** & & *** & $* * *$ & *** & & $* * *$ & $* * *$ & $* * *$ & & $* * *$ & $* * *$ & $* * *$ & \\
\hline Nontreated & & 3.0 & & & & 5.8 & & & & 49 & & & & 68 & & \\
\hline
\end{tabular}

${ }^{2} \mathrm{~L}=$ linear model for the soaking time effects.

${ }^{y}$ Seedlings emerged from these seeds were dead by 39 DAS.

${ }^{\mathrm{x}} \mathrm{L}=$ linear model for paclobutrazol concentration effects.

$\mathrm{NS}^{*, * * * * * * *}$ Nonsignificant or significant at $P \leq 0.001,0.01$, or 0.05 , respectively.

Table 2. Height $(\mathrm{cm})$ and emergence (\%) of verbena seedlings from seeds primed in aerated -1.0 MPa solutions of polyethylene glycol 8000 (PEG) containing $0,10,50,200$, or $500 \mathrm{mg} \cdot \mathrm{L}^{-1}$ paclobutrazol for $26 \mathrm{~h}$ (DP) or PEG only for $26 \mathrm{~h}$ and then soaked in $0,10,50,200$, or $500 \mathrm{mg} \cdot \mathrm{L}^{-1}$ paclobutrazol solutions for 5 min (AP). Percentage emerged seedlings was determined at 10 and $20 \mathrm{~d}$ after sowing (DAS), while shoot height was determined at 20 and 60 DAS

\begin{tabular}{|c|c|c|c|c|c|c|c|c|c|c|c|c|}
\hline \multirow[b]{3}{*}{ Paclobutrazol concn } & \multicolumn{5}{|c|}{ Shoot ht (cm) } & & \multicolumn{5}{|c|}{ Emergence $(\%)$} & \multirow[b]{3}{*}{$\mathrm{t}$} \\
\hline & \multicolumn{2}{|c|}{$20 \mathrm{DAS}$} & \multirow[b]{2}{*}{$\mathrm{t}$} & \multicolumn{2}{|c|}{$60 \mathrm{DAS}$} & \multirow[b]{2}{*}{$\mathrm{t}$} & \multicolumn{2}{|c|}{$10 \mathrm{DAS}$} & \multirow[b]{2}{*}{$\mathrm{t}$} & \multicolumn{2}{|c|}{$20 \mathrm{DAS}$} & \\
\hline & $\mathrm{DP}$ & AP & & $\mathrm{DP}$ & $\mathrm{AP}$ & & DP & AP & & $\mathrm{DP}$ & $\mathrm{AP}$ & \\
\hline $0 \mathrm{mg} \cdot \mathrm{L}^{-1}$ & 1.9 & 1.9 & NS & 5.4 & 5.4 & NS & 9 & 9 & NS & 72 & 72 & NS \\
\hline $10 \mathrm{mg} \cdot \mathrm{L}^{-1}$ & 1.8 & 1.8 & NS & 5.4 & 5.6 & NS & 10 & 10 & NS & 52 & 46 & NS \\
\hline $50 \mathrm{mg} \cdot \mathrm{L}^{-1}$ & 1.9 & 1.9 & NS & 5.2 & 5.0 & NS & 9 & 4 & NS & 52 & 40 & NS \\
\hline $200 \mathrm{mg} \cdot \mathrm{L}^{-1}$ & 1.6 & 1.8 & NS & 5.0 & 5.0 & NS & 3 & 1 & NS & 26 & 23 & NS \\
\hline $500 \mathrm{mg} \cdot \mathrm{L}^{-1}$ & 1.8 & 1.9 & NS & 4.2 & 5.0 & NS & 3 & 0 & NS & 14 & 5 & NS \\
\hline $\mathrm{L}^{\mathrm{y}}$ & NS & NS & & $* *$ & NS & & $*$ & $* * *$ & & $* * *$ & $* * *$ & \\
\hline Nontreated & \multicolumn{2}{|c|}{2.4} & & \multicolumn{2}{|c|}{7.0} & & \multicolumn{2}{|c|}{58} & \multicolumn{4}{|c|}{74} \\
\hline
\end{tabular}

${ }^{2} \mathrm{t}=$ Mean comparisons by LSD at $P \leq 0.05$.

${ }^{\mathrm{y}} \mathrm{L}=$ linear model for paclobutrazol concentration effects.

NS,*,**,****Nonsignificant or significant at $P \leq 0.001,0.01$, or 0.05 , respectively. 
Table 3. Height $(\mathrm{cm})$ of verbena seedlings from seeds coated with Celgard 96530 or Disco Shine containing 0,10 , or $500 \mathrm{mg} \cdot \mathrm{L}^{-1}$ paclobutrazol (DC) or Celgard 96530 or Disco Shine only and then soaked in 0 , 10 or $500 \mathrm{mg} \cdot \mathrm{L}^{-1}$ water solutions of paclobutrazol during $1 \mathrm{~min}(\mathrm{AC})$. Measurements were taken 20 and $40 \mathrm{~d}$ after sowing (DAS).

\begin{tabular}{|c|c|c|c|c|c|c|}
\hline \multirow[b]{3}{*}{ Paclobutrazol concn } & \multicolumn{6}{|c|}{ Shoot ht $(\mathrm{cm})$} \\
\hline & \multicolumn{2}{|c|}{20 DAS } & \multirow[b]{2}{*}{$\mathrm{t}^{2}$} & \multicolumn{2}{|c|}{40 DAS } & \multirow[b]{2}{*}{$\mathrm{t}$} \\
\hline & $\mathrm{DC}$ & $\mathrm{AC}$ & & $\mathrm{DC}$ & $\mathrm{AC}$ & \\
\hline \multicolumn{7}{|l|}{ Celgard 96530} \\
\hline $0 \mathrm{mg} \cdot \mathrm{L}^{-1}$ & 1.2 & 1.0 & NS & 4.6 & 4.6 & NS \\
\hline $10 \mathrm{mg} \cdot \mathrm{L}^{-1}$ & $-y^{y}$ & 1.6 & NS & 4.2 & 3.8 & NS \\
\hline $500 \mathrm{mg} \cdot \mathrm{L}^{-1}$ & --- & --- & --- & 3.6 & 3.2 & NS \\
\hline $\mathrm{L}^{\mathrm{x}}$ & NS & NS & & $*$ & $* *$ & \\
\hline \multicolumn{7}{|l|}{ Disco Shine } \\
\hline $0 \mathrm{mg} \cdot \mathrm{L}^{-1}$ & 1.6 & 1.2 & NS & 4.2 & 4.2 & NS \\
\hline $10 \mathrm{mg} \cdot \mathrm{L}^{-1}$ & 2.0 & 1.8 & NS & 4.0 & 4.2 & NS \\
\hline $500 \mathrm{mg} \cdot \mathrm{L}^{-1}$ & --- & -- & --- & 1.4 & 3.0 & NS \\
\hline $\mathrm{L}$ & NS & NS & & $* * *$ & * & \\
\hline Nontreated & \multicolumn{2}{|c|}{2.8} & \multicolumn{4}{|c|}{5.6} \\
\hline
\end{tabular}

$\mathrm{z}_{\mathrm{t}}=$ Mean comparisons by LSD at $P \leq 0.05$.

${ }^{y}$ Seedlings did not emerge from these seeds.

${ }^{\mathrm{x}} \mathrm{L}=$ linear model for paclobutrazol concentration effects.

NS,,${ }^{* * *, * * *}$ Nonsignificant or significant at $P \leq 0.001,0.01$, or 0.05 , respectively.

Seed priming. Increasing paclobutrazol concentration was not associated with reduced seedling growth $60 \mathrm{DAS}$, unless paclobutrazol was present in the priming solution(DP)(Table 2). The duration of paclobutrazol contact with the seeds (short in AP and long in DP) did not influence reductions in seedling height. Seedling emergence percentage from primed seeds at 10 DAS was lower than from nontreated seeds, while no difference in percentage emergence was observed 20 DAS between nontreated and PEG only primed seeds (Table 2). Applying paclobutrazol to seeds either during (DP) or after (AP) seed priming reduced seedling emergence (Table 2).

Seed coating. A large reduction in verbena seedling emergence was observed when seeds were coated with either coating formulation. Emergence of seeds coated with synthetic polymers did not exceed $10 \%$ at 30 DAS (data not presented). Application of paclobutrazol to seeds during (DC) or after (AC) coating procedure did not improve seedling emergence.

Coating verbena seeds with either polymer significantly reduced seedling height (Table 3 ) and contributed to nonuniform seedling growth (data not shown). The two coating formulation treatments did not affect seedling height. Increasing paclobutrazol concentration in the coating formulation linearly reduced seedling height at 40 DAS (Table 3). Measurement of seedling height during earlier periods was not possible in some treatments due to the absence of emerged seedlings.

\section{Pansy}

Increasing paclobutrazol concentrations during soaking resulted in decreased seedling height. At both 40 and 54 DAS, soaking for 1 min was associated with a height reduction only with $30 \mathrm{mg}$ paclobutrazol/L concentration (Table 4). Measurement of seedling height earlier than 40 DAS was not possible because seedlings were too small.

Seedling emergence percentage at 8 DAS declined with increasing paclobutrazol concentration for both soaking times (Table 4). However, by 12 DAS, this trend was observed only for seeds soaked during $5 \mathrm{~min}$. Seedling emergence was delayed the most when seeds were soaked in the highest paclobutrazol rate (30 $\mathrm{mg} \cdot \mathrm{L}^{-1}$ ) (Table 4).

\section{Celosia}

Although celosia seedling height decreased with increasing paclobutrazol concentration (Table 5), this effect was minimal. Increasing time of seed soaking did not affect seedling height at any paclobutrazol concentration (Table 5). Increasing paclobutrazol concentration reduced seedling emergence at $3 \mathrm{DAS}$, although the reductions were negligible (Table 5). Soaking time had no effect on seedling emergence (Table 5).

\section{Discussion}

Reduction and delay of seedling emergence can be undesirable side effects from treating seeds with paclobutrazol (Aufhammer et al., 1993; Pasian and Bennett, 2001). These effects may be explained by paclobutrazol penetration in seeds and subsequent lowering of seedling GA contents (Pill and Gunter, 2001; Pombo et al., 1985). Since GA is involved in the elongation of seedling axis organs (Bewley and Black, 1994), we suggest that lower GA levels may have caused slower radicle and shoot elongation and delayed seedling emergence in verbena

Table 4. Height (cm) and emergence (\%) of pansy seedlings from seeds soaked in $0,2,10$, or $30 \mathrm{mg} \cdot \mathrm{L}^{-1}$ paclobutrazol solutions during 1 or 5 min. Numbers of emerged seedlings were determined 8 and $12 \mathrm{~d}$ after sowing (DAS) while seeding heights were measured 40 and 54 DAS.

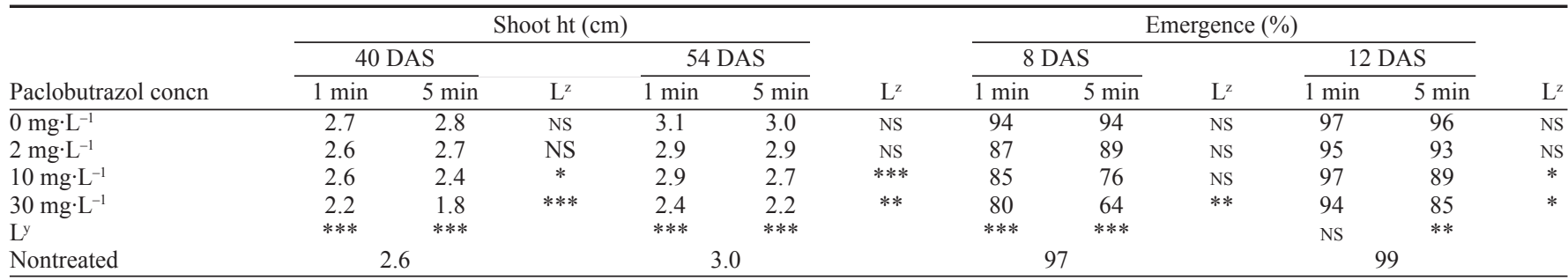

${ }^{2} \mathrm{~L}=$ linear model for the soaking time effects.

${ }^{\mathrm{y}} \mathrm{L}=$ linear model for paclobutrazol concentration effects.

${ }^{\mathrm{NS}, *, * *, * * *}$ Nonsignificant or significant at $P \leq 0.001,0.01$, or 0.05 , respectively.

Table 5. Height (cm) and emergence (\%) of celosia seedlings from seeds soaked in $0,10,50,200$, or $500 \mathrm{mg} \cdot \mathrm{L}^{-1}$ paclobutrazol solutions for 5, 180 , or $360 \mathrm{~min}$. Numbers of seedlings that emerged were observed 3 and $15 \mathrm{~d}$ after sowing (DAS), while height measurements were taken 10 and 24 DAS.

\begin{tabular}{|c|c|c|c|c|c|c|c|c|c|c|c|c|c|c|c|c|}
\hline \multirow[b]{3}{*}{ Paclobutrazoconcn } & \multicolumn{7}{|c|}{ Shoot ht $(\mathrm{cm})$} & \multicolumn{9}{|c|}{ Emergence (\%) } \\
\hline & \multicolumn{3}{|c|}{$10 \mathrm{DAS}$} & \multicolumn{4}{|c|}{$24 \mathrm{DAS}$} & \multirow[b]{2}{*}{$\mathrm{L}^{\mathrm{z}}$} & \multicolumn{3}{|c|}{3 DAS } & \multirow[b]{2}{*}{$\mathrm{L}^{\mathrm{z}}$} & \multicolumn{3}{|c|}{$15 \mathrm{DAS}$} & \multirow[b]{2}{*}{$\mathrm{L}^{\mathrm{z}}$} \\
\hline & $5 \mathrm{~min}$ & $180 \mathrm{~min}$ & $360 \mathrm{~min}$ & $\mathrm{~L}^{\mathrm{z}}$ & $5 \min$ & $180 \mathrm{~min}$ & $360 \mathrm{~min}$ & & $5 \mathrm{~min}$ & $180 \mathrm{~min}$ & $360 \mathrm{~min}$ & & $5 \min$ & $180 \mathrm{~min}$ & $360 \mathrm{~min}$ & \\
\hline $0 \mathrm{mg} \cdot \mathrm{L}^{-1}$ & 1.6 & 1.6 & 1.6 & NS & 5.0 & 4.9 & 4.9 & NS & 85 & 90 & 88 & NS & 89 & 92 & 95 & NS \\
\hline $10 \mathrm{mg} \cdot \mathrm{L}^{-1}$ & 1.6 & 1.6 & 1.6 & NS & 5.0 & 4.9 & 4.9 & NS & 90 & 83 & 90 & NS & 95 & 89 & 97 & NS \\
\hline $50 \mathrm{mg} \cdot \mathrm{L}^{-1}$ & 1.6 & 1.6 & 1.5 & NS & 5.1 & 4.9 & 5.0 & NS & 86 & 89 & 91 & NS & 93 & 91 & 97 & NS \\
\hline $200 \mathrm{mg} \cdot \mathrm{L}^{-1}$ & 1.5 & 1.6 & 1.5 & NS & 5.0 & 5.0 & 4.9 & NS & 86 & 86 & 92 & NS & 91 & 93 & 95 & NS \\
\hline $500 \mathrm{mg} \cdot \mathrm{L}^{-1}$ & 1.4 & 1.5 & 1.5 & NS & 4.8 & 4.8 & 4.9 & NS & 84 & 88 & 85 & NS & 91 & 91 & 93 & NS \\
\hline $\mathrm{L}^{\mathrm{y}}$ & $* * *$ & $* *$ & * & & $* * *$ & NS & NS & & $*$ & $*$ & $*$ & & $*$ & NS & NS & \\
\hline Nontreated & & 1.5 & & & & 5.0 & & & & 91 & & & & 94 & & \\
\hline
\end{tabular}

${ }^{\mathrm{z}} \mathrm{L}=$ linear model for the soaking time effects.

${ }^{y} \mathrm{~L}=$ linear model for paclobutrazol concentration effects.

NS, ${ }^{*}, * * * * * *$ Nonsignificant or significant at $P \leq 0.001,0.01$, or 0.05 , respectively. 
and pansy. Absence of seedling emergence might indicate paclobutrazol penetration into seeds in amounts sufficient to reduce endogenous GA levels below those required for seedling development. Therefore, an optimal seed treatment should allow paclobutrazol to enter the seed in the amount that reduces growth, without affecting seedling emergence.

Alternatively, it is possible that after seed soaking, paclobutrazol remains attached to the seedcoat rather than penetrate the seed (Pasian and Bennett, 2001). Coat-associated paclobutrazol might be further released to the growth media and absorbed by the developing root. According to this hypothesis, an optimal seed treatment should be able to keep paclobutrazol outside the embryo, while seedcoats act as a carrier for paclobutrazol (Pasian and Bennett, 2001). In our experiment, longer soaking time provided more chance for paclobutrazol to penetrate the seeds of verbena and pansy. In a preliminary study, soaking pansy seeds in 50 to $1000 \mathrm{mg}$ paclobutrazol/L solutions for 5 to 180 min was associated with larger reductions in seedling height and emergence (data not shown) than observed in this experiment. Therefore, reduced seedling emergence with increasing paclobutrazol concentration and soaking duration suggests that more paclobutrazol moved into the seeds during soaking. At the same time, seed soaking in paclobutrazol solutions for $1 \mathrm{~min}$ (pansy) or $5 \mathrm{~min}$ (pansy, verbena) was associated with reduced seedling height. Such short soaking durations seem unlikely to allow the growth regulator adequate time to penetrate the seed. We speculate that in this case paclobutrazol was in the seedcoats, rather than in interior seed parts.

Different morphological and biochemical seed characteristics might affect the result of seed soaking in paclobutrazol solutions. Reduced seedling emergence of verbena observed in our experiment might have been due to several natural constraints, such as post-harvest dormancy (Grzesik et al., 1998) or hilum morphology (Maekawa and Carpenter, 1991; Chojnowski etal., 1998). The last factor caused imbibitional restriction of verbena germination, when swelling of hilum walls contributed to hilum closure and restricted oxygen supply to the embryo (Maekawa and Carpenter, 1991). However, in our study, soaking procedure was not responsible for lower seedling emergence in verbena, since this did not differ between water soaked and nonsoaked seeds. Low seedling emergence in verbena was possibly due in part to hardseededness, since basal (hilum removal) or apical scarification improved germination (Chojnowski et al., 1998).

Priming is thought to have less detrimental effect on verbena seedling emergence as compared with soaking, since it facilitates gradual seed imbibition, which is necessary for increasing seed metabolism and preventing imbibitional damage (Khan, 1992; Still and Pill, 2003). However, priming also provided longer seed contact with paclobutrazol indicating that more growth regulator could move inside the seeds and cause toxicity. Reduced seedling emergence from coated verbena seeds might be explained by the properties of the artificial seedcoats. According to Taylor et al. (2001), synthetic polymers may act as a barrier to oxygen diffusion through the seedcoats thus contributing to lower seedling emergence. Therefore, while coating verbena seeds with paclobutrazol resulted in seedling height reduction, this method is unacceptable for seedling growth control due to a drastic reduction of seedling emergence.

The growth reduction of celosia seedlings, although significant, is such that limits the practical value of soaking seeds in paclobutrazol for this crop. It can be speculated that soaking celosia seeds in paclobutrazol solutions did not affect seedling height because of seedcoat properties or GA biosynthesis patterns. Seedcoats represent a barrier for some growth regulators (Pressman and Shaked, 1988). High seed GA content made growth regulators ineffective in inhibiting germination regardless of the presence of seedcoats (Edelstein et al., 1995). We can speculate that GA was already synthesized in celosia seeds by the time of paclobutrazol applications

Important problems that remain unstudied in this research are 1) the precise location of paclobutrazol in treated seeds, 2) the ability of paclobutrazol to be released from the seedcoats to the substrate, and 3) the optimal rate and amount of this release for controlling seedling height.

\section{Literature Cited}

Aufhammer, W., A.M. Steiner, S. Zaborszky, and J. Gobel. 1993. Effects of seed treatments with growth retardants on germination and field emergence of winter barley and winter rape. Bodenculture 44:229-242.

Bewley, J.D. and M. Black. 1994. Seeds: Physiology of development and germination. Plenum Press, New York.

Carpenter, W.J. and S. Maekawa. 1991. Substrate moisture level governs the germination of verbena seed. HortScience 26:1469-1472.

Cho, K.C., W.M., Yang, W.S. Kim, and S.J. Chung. 2002. Growth retardation of cucumber $(\mathrm{Cu}$ cumis sativus L.) seedlings by treatment of paclobutrazol and removal of retardation by foliar spray of gibberellin. J. Kor. Soc. Hort. Sci. 43: 415-420.

Choi, C.D., S.C., Kim, and S.K. Lee. 1988. Agricultural use of the plant growth regulator. I. Controlling rice seedling growth by seed soaking treatment. Res. Rpt. Rur. Dev. Admin. 30:24-29.
Chojnowski, M., A. Wilkonska, and M. Grzesik. 1998. Germination responses of seeds of three Verbena $\times$ hybrida cultivars to temperature and scarification treatments. J. Fruit Ornamental Plant Res. 6:95-101.

Dale, A.E. and D.S.H. Drennan. 1997. Transplanted maize (Zea mays) for grain production in southern England. III. Effects of plant growth regulator treatments on maize transplant morphology. J. Agr. Sci. 128:45-50.

Edelstein, M., Y.B. Tal, M. Wodner, and J. Kigel. 1995. Role of endogenous gibberellins in germination of melon (Cucumis melo) seeds. Physiol. Plant. 95:113-119.

Grzesik, M., K. Gornik, and M.G. Chojnowski. 1998. Effect of environmental conditions and the harvest time on the seed yield quality of Verbena $x$ hybrida Voss. Seed Sci. Technol. 26:131-140.

Fletcher, A., A. Gilley, N. Sankhla, and T. Davies. 2000. Triazoles as plant growth regulators and stress protectants. Hort. Rev. 24:55-138.

Gent, M.P.N. 1997. Persistence of triazole growth retardants on stem elongation of Rhododendron and Kalmia. J. Plant Growth Regulat. 16:193-203.

Hamid, M.M. and R.R. Williams. 1997. Translocation of paclobutrazol and gibberellic acid in Sturt's desert pea (Swainsona formosa). Plant Growth Regulat. 23, 167-171.

Khan, A.A. 1992. Preplant physiological seed conditioning. Hort. Rev. 13:131-181.

Klock, K.A., 1998. Influence of urban waste compost media and paclobutrazol drenches on impatiens growth. HortScience 33:277-278.

Maekawa, S. and W.J. Carpenter. 1991. Verbena seed hilum morphology contributes to irregular germination. HortScience 26:129-132.

Million, J.B., J.E. Barrett, T.A. Nell, and D.G. Clark. 1999. Paclobutrazol distribution following application to two media as determined by bioassay. HortScience 34:1099-1102.

Pasian, C.C. and M.A. Bennett. 2001. Paclobutrazol soaked marigold, geranium, and tomato seeds produce short seedlings. HortScience 36:721-723.

Pill, W.G. and J.A. Gunter. 2001. Emergence and shoot growth of cosmos and marigold from paclobutrazol-treated seed. J. Env. Hort. 19:11-14.

Pombo, G., M.D., Tukey, L.D., Orzolek, and T.P. Pyzik. 1985. The effect of paclobutrazol, daminozide, glyphosate and 2,4-D in gel on the emergence and growth of germinated tomato seeds. J. Hort. Sci. 60:353-357.

Pressman, E. and R. Shaked. 1988. Germination of annual celery Apium graveolens seeds inhibition by paclobutrazol and its reversal by gibberellins and benzyladenine. Physiol. Plant. 73:323-326.

Rademacher, W. 2000. Growth retardants: effects on gibberellin biosynthesis and other metabolic pathways. Annu. Rev. Plant Physiol. Plant Mol. Biol. 51:501-531.

Still, J. and W. Pill. 2003. Germination, emergence, and seedling growth of tomato and impatiens in response to seed treatment with paclobutrazol. HortScience 38:1201-1204.

Taylor,A.G., C.J. Echenrode, and R.W. Straub. 2001. Seed coating technologies and treatments for onion: Challenges and progress. HortScience 36:199-205. 